Published as: *'New Governance, Green Planning \& Sustainability: Reviewing Tasmania Together and Growing Victoria Together' Australian Journal of Public Administration (with Brian Coffey) 66(1), 23-37.

\title{
NEW GOVERNANCE, GREEN PLANNING \& SUSTAINABILITY: TASMANIA TOGETHER AND GROWING VICTORIA TOGETHER
}

\begin{abstract}
Bridgman and Davis (2000:91) have argued that 'ideally government will have a well developed and widely distributed policy framework, setting out economic, social and environmental objectives'. This paper compares and evaluates two such frameworks or plans, Tasmania Together and Growing Victoria Together, in terms of their potential to promote sustainability. It argues that they are very different exercises in new governance, aimed at reconnecting with community priorities and at redirecting macro-policy setting away from a preoccupation with economic priorities, respectively. Nevertheless both plans have the capacity to 'green' state planning, in Tasmania in terms of more purposeful benchmarks, and in Victoria in terms of enhanced sustainability emphasis in the macro-policy setting. The paper encounters tensions in its review of the plans between deliberation and planning, policy empowerment and policy progress, and policy institutionalisation and politicisation as means of achieving policy change. It finds that whilst Tasmania and Victoria are re-engaged states that are reinventing state policy, as yet they are failing to meet the governance challenges of sustainability.
\end{abstract}

\section{INTRODUCTION}

The Labor governments in Tasmania and Victoria have developed strategic plans (Tasmania Together and Growing Victoria Together) that articulate medium term (10-20 year) policy directions for their states ${ }^{1}$. We suggest here that these frameworks can be compared and contrasted in terms of the opportunities they afford for promoting sustainability. Both resonate with the agenda of reinvented government in the wake of decades of market driven policymaking (Osborne and Gaebler 1992). Both also signal a revival of interest in planning, and offer potential for pursuing environmental sustainability, notwithstanding the challenges (Yencken 2002) that would entail. Whilst sharing commonalities, the two plans nevertheless represent different styles - with the Tasmanian process more strongly driven by the community, and the Victorian process more clearly articulating a strategic agenda to distance the government from the economically rationalist Kennett years. Whilst Tasmania's plan is derived from a bottom-up process, Victoria's plan is delivered top down. Despite their differences, however, both plans make significant commitments to sustainability, in Tasmania with the adoption of environmental goals, benchmarks and indicators, and in Victoria with the adoption of the triple bottom line.

We turn in this paper to two contrasting bodies of literature, new governance and green planning, in order to derive principles by which to evaluate the sustainability potential of the two plans. The utility of new governance literature as a source of evaluative material is in its concern with the re-engaged state and its drawing of the community into policy development (Bingham, Nabatchi and O'Leary 2005:548). New governance literature extols the benefits of state reflexivity, with the promotion of deliberative policy development that is well conceived, practiced and reinvented through significant community engagement. This literature provides a set of principles by which to review the Tasmania Together and Growing Victoria Together plans such as the extent to which these are apolitical ${ }^{2}$, deliberative, power sharing, embedded and lasting in the institutional sense (Rhodes 1997; Lundqvist 2001; Reddel 2002). On the other hand, the green planning literature is designed for analysing the pursuit of sustainability, and fits

\footnotetext{
${ }^{1}$ At the time of writing, Tasmania Together was undergoing its first five year review and a refreshed version of Growing Victoria Together had just been released. This paper is concerned with the initial versions of both plans. ${ }^{2}$ Apolitical is used throughout in the sense of being beyond party and short term electoral politics.
} 
very well with the practice of state planning being examined here. This literature emphasises state commitment as a key principle in the pursuit of sustainability, and advocates processes that are comprehensive, participatory, integrated and adaptive or capable of iterative reform (DalalClayton 1996; Selman 1999; Buhrs 2000).

The approach taken in this paper is comparative in Rose's (1991:439) sense of presenting 'empirical evidence of some kind in an attempt to compare systematically and explicitly' in this case two state planning exercises. Comparative analysis helps avoid the assertion of uniqueness through false particularisation, (Rose 1991:450), in this case helping to avoid the finding that there is one best policy pathway to pursuing state sustainability. In keeping with the comparative method, this paper develops a set of concepts from a review of two bodies of literature which allows us to test our hypothesis that sub-national plans offer potential for pursuing sustainability. We have not attempted to compare two similar case studies, but have chosen two contrasting studies, using the contrasting theories of new governance and green planning to enable us to analyse the tensions we encounter. These theories allow us to situate and discuss tensions between deliberation and planning, between policy empowerment and policy progress, and between policy institutionalisation and politicisation. The analysis undertaken here of the state plans provides a useful test of the 'robustness and transferability' of the concepts of new governance and green planning, and a means of reflecting upon their utility (Mackie and Marsh 1995:176).

The paper firstly reviews new governance and green planning for sustainability, before turning to an account, analysis and discussion of Tasmania Together and Growing Victoria Together. We broadly adopt Salamon's (2002) conception of new governance, which sees policy as a collaborative exercise, that engages a range of policy networks, that reshapes the way government works, and that steers administration from hierarchy towards empowerment. We adopt Dalal-Clayton's (1996) definition of green planning as the development of comprehensive and integrated policies, plans and strategies to address environmental problems, with sustainability as their goal. By sustainability, we mean the 'use, conservation and enhancement of the community's resources so that ecological processes, on which life depends, are maintained, and the total quality of life, now and in the future, can be increased' (Commonwealth 1992:128). We take a macro-overview in analysing state planning, and have left the detailed attention of how to make the two plans more purposefully articulate in pursuing sustainability objectives to work elsewhere (Crowley 2006; Coffey and Major 2005). We are also concerned here with sustainability potential rather than outcomes, which would require an evaluation entirely beyond the scope of this paper and its concern with state planning processes.

\section{NEW GOVERNANCE, GREEN PLANNING \& SUSTAINABILITY New Governance}

Governance is a notion that is at once ill defined but also well understood as referring to the changed role of government in contemporary times. Government has moved beyond its post World War Two largess and legitimacy, through the straitening and turbulent reforms of the 1980 s, to arrive in the post strong state era of the twenty first century. Over that time government has also moved from the act of governing with sole authority and legitimacy, to the need to govern in more complex ways today by steering, partnering and devolving (Considine 2005:165). If government is essentially about the process of acting with total authority and legitimacy, then governance has become about extending this process beyond the state, raising the question of the extent to which authority and legitimacy can be assumed beyond government. Pierre and Peters (2000:1) define governance as covering the whole range of institutions and relations involved in the process of governing, with its appeal being in making political science more policy relevant and in raising the issue of how to pursue collective goals. Governance is 
thus to varying degrees a power sharing, deliberative process in pursuit of collective ends but one that complements the traditional policy making roles of the state.

Some refer to new governance as the placing of particular emphasis upon the involvement of society in the process of governing (Pierre and Peters 2000:7). It is a term referred to by several authors that varies, Lundqvist observes, between the extremes of governing by state control and governing by increasing societal control over policy. For example Pierre and Peters locate the state at the centre of the structures and processes of governance whilst juxtaposing this with new governance in Rhodes's sense as governing at times without government (Lundqvist 2001:321; Pierre and Peters 2000; Rhodes 1997). Rhodes (1997) presents a complex picture of the varying meanings of increasing societal control. These range from minimal state involvement at one extreme to self-organising networks at the other. He explains that networks offer a 'third way' beyond either the state or the market for acting authoritatively in service delivery. These are not only self-organising and inter-organisational, but are also capable of resisting government steering, developing their own policies and moulding their own environments (Rhodes 1997:53).

Reddel's conception of new governance is 'based on the themes of dialogue, deliberation and association'. This offers promise 'as a policy framework that can re-conceptualise the statecommunity (and market) relationship and deliver improved community outcomes'. His emphasis is upon new governance in the context of place based or spatial policies. If new governance involves bringing society back in to policy making, then in Reddel's sense this is place specific and represents a rediscovery of community in response to the 'anti-state crisis' (Reddel 2002:545). New governance is then also an acknowledgment of this crisis, which is manifest as the broadly perceived remoteness, irrelevance and untrustworthiness of representative politics, and the need 'to establish legitimacy in the face of the erosion of public trust' (Bishop and Davis 2001:191). New governance in this societal driven sense is both a move toward deliberative, partnership building (Hodgett and Johnson 2001) and a way of working together in consensual, apolitical fashion beyond the adversarial political arena.

Tasmania Together and Growing Victoria Together can both be seen as new governance exercises at least in the sense that their very broad impetus was community disillusionment with politics and thus heightened dissatisfaction. They belong, albeit as contrasting experiments, to the move towards more and better participatory democracy in response to the distrust of politics and politicians that is the key problem of liberal democracy today (Davis and Weller 2001). In both cases for very different reasons there was a fundamental policy re-visioning and machinery of government reorientation driven by a sense of 'bringing society back in'. In terms of more than rhetorically reaching out to the community, we are interested here in the extent to which the plans were beyond a narrow conception of self-interested politics, were deliberatively derived, were empowering of the community and were embedded to effect broad and lasting change. Given their emphasis on the environment in Tasmania Together and Growing Victoria Together, reflecting the historical politicisation of 'environment' and the unresolved disputes in both states, we are interested in the sustainability potential of both plans.

\section{Green Planning for Sustainability?}

Governments can approach sustainability in a range of ways, from policy principles to legislative prescription, and at various levels, from national to state to local. Whilst much attention has been paid to national initiatives, this paper is concerned with the more neglected state level and state planning as a potential vehicle for pursuing sustainability. Green planning is a diverse activity that can be undertaken using a range of approaches for a range of objectives and, importantly, may be informed by deliberation or design (Kay and Alder 1999). Green planning is also very much a rational-comprehensive exercise whereby the 'ends' are identified in advance and the 'means' are sought to achieve them (Richardson and Jordan 1979:21) albeit subject to iterative redesign in implementation. There is also confusing use of the terms 'green 
planning' and 'sustainability planning' with Australia's Ecologically Sustainable Development process, that was pioneered in the late 1980s, referred to as either or both (Buhrs 2000).

We define green planning as the development of comprehensive and integrated policies, plans and strategies to address environmental problems, with sustainability as their goal (DalalClayton 1996). Green planning proposes to make sustainability concrete, by setting milestones for improvements in environmental quality, generating or strengthening public support for environmental measures, and enhancing transparency and accountability (Selman 1999). The performance of public and private actors are measured against specific milestones (Buhrs 2000), just as the achievements of Tasmania Together and Growing Victoria Together are measured against indicators and objectives. Public support is critical however. Indeed 'enhancement of public participation in environment and development decision-making is generally understood as an essential characteristic of governance for sustainable development' (Meadowcroft 2004:162). Whether or not a green plan is to gain ongoing community and government support will depend on how it was generated, with an inclusive, democratic process the most likely to generate acceptance (Buhrs 2000:119-20).

One of the defining features of green planning is the emphasis on the integration of environmental objectives, not just into non-environmental policy areas but across government at all levels, and into partnerships with community and business. The OECD (2002) sees integration as an overarching goal beyond the quick fix and about specific commitments by governments to economy, ecology and society in equal measure, with institutional adjustments made to turn commitment into practice. Integration remains a challenge in industrialised countries with most developing green plans and sustainability plans independently of their national plans, with the notable exceptions of Denmark, France and New Zealand. And few such countries link green plans, sustainability plans and budget processes, again with the exceptions of Canada, France, the Netherlands, New Zealand and Norway (Dalal-Clayton 1996:50-53). Hertin and Berkhout (2003:40) see no improved integration in sight, observing that although the challenge of integration has been debated for decades, environmental policy practice is largely unchanged (see also Coffey and Major 2005).

Yencken (2002) also argues that there must be a substantive understanding and appreciation of the scope of ecological problems, matched by a strong political commitment to address these in no uncertain terms over time. Effective green planning for sustainability policy thus requires an ongoing commitment to, and continuity of, knowledge generation and review. In the case of conclusive data being unavailable, partnerships can be encouraged by government policies to mobilise finances for research and development and to ensure that the knowledge generated is widely shared, debated and understood (OECD 2002). Equally important is an adaptive approach to management to deal with the emergence of new knowledge and to ensure that decision making is always well informed by appropriate data (Dovers 1999). Related to this is the need for ongoing review during implementation, and effective monitoring, evaluation and reporting as a means of tracking and reviewing progress, as is typical of state planning. State planning is thus a potential vehicle for green planning for sustainability.

\section{STATE PLANNING IN TASMANIA AND VICTORIA}

The new governance and green planning literature has considerable overlap in terms of reviewing state planning for achieving sustainability to which we will return. From the literature above, there is, for example, similar emphasis upon deliberation as problem solving in new governance and green planning - in terms of overcoming public alienation and of rescuing the environment respectively. Political commitment is significant for both in terms of assuaging public cynicism, and moving past rhetorical efforts to achieve sustainability, although bipartisanship, working together and apolitical support is increasingly expected. Knowledge generation and management is also emerging as a significant issue in terms of setting meaningful goals, targets and benchmarks in state and green planning, but also in terms of integrating and 
adapting knowledge across sectors. There are tensions between new governance and strategic planning as policy styles that do interest us here, as we consider Tasmania Together and Growing Victoria Together, and that are picked up in subsequent discussion. These tensions are between deliberation and planning, between empowerment and policy change, and between institutional and political routes to embedding policy.

\section{Tasmania Together}

The Bacon Labor government was elected in August 1998 following the demise of the shortlived 1996-98 Liberal minority government that had been supported in power by the Greens. The Premier saw the need for uniting Tasmanians as a priority, and began consulting around the concept of Tasmania Together six months later. Tasmania Together is an Australian first, a people driven 20 year social, environmental and economic plan, but one also strongly driven in terms of leadership, conviction and process from the top. The inspiration for it came nearly a decade earlier when former state premier Michael Field discovered the Oregon Shines state plan during his Labor Listens community consultation process ${ }^{3}$. The Bacon government also needed to distance itself from the previous Liberal minority government's well-respected Directions project which had itself been an attempt to remedy poor state planning. The Labor solution was a development and social partnership agenda comprising Tasmania Together, Local Government Partnerships and Industry Councils with a mandate for industry planning (Kent 2000).

Tasmania Together ${ }^{4}$ has moved policy making to long term with the community shaping its own well being, culture, democracy, economy and environment, and with community vision affecting the forward planning of government agencies. The intent was for Tasmania Together to be an apolitical exercise linking the community with public policy in an open, transparent way to achieve measurable long-term objectives that are target based with time-lines, indicators and progress reports. The framework was designed by a Community Leaders Group with extensive community input, and expert benchmarking groups then working on the detail of its objectives, but it is now managed by an independent, legislatively mandated Progress Board. The Progress Board steers the implementation of Tasmania Together on the understanding that it is not owned by the state government or tied to its political fortunes. Tasmania Together's vision and goals belong to the community and are intended to be pursued by the community, its individuals, groups, public and private interests, the Progress Board, and all levels of government.

Tasmania Together's implementation measures include reorienting agency priorities towards the need to address its benchmarks, in priority clusters, and the budget prioritisation of agency submissions that are linked to achieving its objectives. In the longer term this will drive agency change by encouraging whole of government approaches to issues, including the gathering and sharing of information relevant to benchmarks, and by financially rewarding joined up approaches. In terms of state government organisation, a Tasmania Together Interdepartmental Committee reviews government activity annually, and the Progress Board reports annually to Parliament against Tasmania Together priorities. Cabinet signs off on priority benchmarks for government activity before sending these to Agencies for incorporation into their planning, budgeting and policy processes, including their devising of cross agency budget submissions. The Progress Board is appointed after expression of interest and has gender, regional, and community balance amongst its seven public members, the remaining two being one university representative and one senior public servant. The Progress Board monitors progress towards the achievement of benchmarks, working with community, business, and government, with support from Department of Premier and Cabinet.

\footnotetext{
${ }^{3}$ The community polarisation in Tasmania surrounding environmental issues in particular from at least the early 1970s with the flooding of Lake Pedder has inspired a range of attempts at community deliberation.

${ }^{4}$ The Tasmania 2020 goals are: to value protect and conserve our natural, cultural and built heritage; to ensure there is a balance between environmental protection and economic and social development; to value, protect and maintain our biological diversity; to ensure our natural resources are managed in a sustainable way now and for future generations (CLG 2000, 2).
} 
Tasmania Together began as an attempt at apolitical planning and is intended to evolve beyond adversarial politics as the community and private sector link their activities to Tasmania Together goals that have become state priorities. Initially it had support from the Liberal Opposition and the Greens, and the State government has not used it for political point scoring, or re-election. The process has attracted controversy however - for the Government's choice of community leaders, for the ejection of dissenters from the Community Leaders Group, and for the capacity of the framework to capture issues. But Tasmania Together's legitimacy was dealt its most severe blow by the late Premier Bacon's refusal to acknowledge the community benchmark for an end to the wood chipping of Tasmania's old growth native forests. There are nevertheless positive signs. The Tasmania Together Progress Board has resisted political pressure with its refusal of the late Premier's request to amend the community's target for an ending to old growth logging. Tasmania Together itself continues to unfold and evolve, now with the support of Premier Paul Lennon, in a transparent and accountable manner, with mandated five yearly reviews, and with legislative capacity to amend and adapt the process.

\begin{tabular}{|c|c|}
\hline DATE & TASMANIA TOGETHER \\
\hline August 1998 & Bacon Labor government elected \\
\hline February 1999 & Tasmania Together initiated \\
\hline May 1999 & 24 member Community Leader's Group formed \\
\hline June 1999 & Search Conference \\
\hline December 1999 & Draft launched for public consultation \\
\hline February/May 2000 & Our vision Our future released for public consultation \\
\hline September 2001 & $\begin{array}{l}\text { Tasmania Together launched - with benchmarks, standards, indicators, and } \\
\text { targets; of } 212 \text { benchmarks, } 99 \text { required clarification by Tasmania Together } \\
\text { Board when established; } 209 \text { were unanimously agreed by the CLG; } 3 \text { were } \\
\text { contested old growth logging; greenhouse; \& ozone. }\end{array}$ \\
\hline June 2002 & Progress tabled in State Parliament \\
\hline July 2002 & Bacon Labor government re-elected (Premier subsequently passes away) \\
\hline June 2003, and 2004 & Progress reports tabled in State Parliament \\
\hline August 2005 & Five year review launched; concluded in August 2006 \\
\hline March 2006 & Lennon Labor government re-elected \\
\hline August 2006 & Progress tabled in State Parliament \\
\hline November- December 2006 & Revised Tasmania Together due to be launched \\
\hline
\end{tabular}

Table 1. Tasmania Together timeline

\section{Growing Victoria Together}

In a result that surprised many people, the Kennett Liberal government lost the 1999 state election to be replaced by a minority Labor government led by Steve Bracks that held office in its first term with the support of three independents (Woodward and Costar 2000). Despite the Labor campaign being highly critical of the market based prescriptions and the leadership style of the Liberal government (O'Neill 2000), after the election there was a sense of not knowing what the Bracks government stood for. Initially this was resolved by the establishment of four pillars of governance - restoring democracy through open and accountable government; responsible financial management; delivering improved services, and promoting growth across the whole state (DPC 2000). In November 2001, the Government released Growing Victoria Together: Innovative State, Caring Communities (DPC 2001) which details its policy priorities. This plan establishes social, environmental and economic goals for the next 10 years, and shows how the Government will lead the way to achieving to them (Office of the Premier 2001) ${ }^{5}$

\footnotetext{
${ }^{5}$ Adams and Wiseman (2003) provide a useful 'insiders' account of the development and rationale underpinning GVT, and how it fits with the Bracks Government's approach to new governance.
} 
Growing Victoria Together ${ }^{6}$ clarified what the government stood for more clearly than its pre-election platforms, despite these being comprehensive and detailed, but this clarification also served a number of related purposes. Although the government was polling strongly there were criticisms about the number of reviews it had instigated and its lack of on-ground activity, leading to quips that Victoria was a 'state of review' with a 'do nothing government' (Chappell 2001). An Age editorial called for the Government to not only steer to completion projects commenced by the previous government, but to articulate its own vision (The Age 2001). Growing Victoria Together became a means of doing this, with a $\$ 1$ billion Growing Victoria Fund to support new infrastructure investment announced in the first budget (2000-2001) (Adams and Wiseman 2003:13). But Growing Victoria Together also indicated priorities, established indicators of progress, and provided a clear, transparent means of ticking off on promises and achievements for years to come. This was critical for building credibility with the public in the lead up to the November 2002 election. ${ }^{7}$

Growing Victoria Together is thus a signpost document that defines priorities and future directions in the post-Kennett era, distancing the Government very clearly in policy terms from the past, and accommodating public and private sector concerns (Ferguson 2001). It works to reintegrate the business of departments in a strategic whole of government sense, and to convey a clear path of reorientation towards achieving strategic goals (Adams and Wiseman 2003:14). After Kennett's economic rationalism, Growing Victoria Together seeks to bring the community and the environment back into policy focus, with the Bracks government looking for broader measures of progress and common prosperity than economic growth alone (DPC 2001).

In terms of implementation, forty-two priority actions are proposed in response to the eleven strategic issues identified. The strategic issues cover education, community services, financial management, safety, transport and communications, sustainable development, jobs and industries, communities, environmental protection, human rights and responsive government. For each issue, the Government states its visions, outlines what it has achieved, lists priority actions, and indicators of progress. The issues and priority actions outlined in Growing Victoria Together guide the Government's budget choices and the directions of government departments, with overall coordination through the Department of Premier and Cabinet (DPC 2001). The indicators of sound financial management are however broadly consistent with the Kennett government's (DPC 2001:12), which leaves the Bracks government open to the criticism that the state's economic framework is unchanged (Hayward and Ewer 2003:16). Furthermore consultation on Growing Victoria Together was limited to key stakeholders and policy insiders, no draft documents or papers were released for feedback, and no independent implementation review body monitors progress.

\begin{tabular}{|l|l|}
\hline DATE & GROWING VICTORIA TOGETHER \\
\hline October 1999 & Bracks Labor government elected \\
\hline March 2000 & Growing Victoria Together Summit held \\
\hline October 2000 & Progress report titled “12 Months on and beyond ..." released \\
\hline November 2001 & Growing Victoria Together released \\
\hline February 2002 & $\begin{array}{l}\text { Snapshot of government achievements released titled Turning } \\
\text { Victoria Around: Delivering Today, Building for Tomorrow }\end{array}$ \\
\hline November 2002 & $\begin{array}{l}\text { Bracks Labor government re-elected with majority in both } \\
\text { Houses of Parliament }\end{array}$ \\
\hline March 2005 & Refreshed version of Growing Victoria Together released \\
\hline November 2006 & State election due \\
\hline
\end{tabular}

\footnotetext{
${ }^{6}$ The Victoria 2010 vision is for: innovation leading to thriving industries generating high quality jobs, environmental protection built into everything that the Government does, caring, safe communities in which opportunities are fairly shared, and for access for all Victorians to the highest quality health and education services throughout their lives (DPC 2001).

${ }^{7}$ Identifying the extent to which Growing Victoria Together contributed to the Government's resounding re-election victory is beyond the scope of this paper, but it is fair to suggest that it would have, at very least, contributed to the impression that the Government knew where it was headed (Hannan 2001).
} 
The two Labor governments have thus chosen very different processes for overcoming past politics, with Tasmania choosing deliberation to move beyond Green supported minority government, and Victoria choosing strategic policy to move beyond the Kennett legacy ${ }^{8}$. Both plans reflect the respective political choices made by Labor governments to allow the community to set the policy agenda in Tasmania, and to wrest the policy agenda away from economic rationalism in Victoria. There is no doubt that both plans have set their stamp on state policy making and are achieving their immediate aims, although it is too early at this stage and beyond the scope of this paper to determine or evaluate how successful they have been. Our interest is in the potential both plans have for pursuing sustainability, Tasmania's by linking its deliberative design up with state of environment reporting processes, and Victoria's by capitalising on the overt political support already expressed by the Premier for sustainability. We turn to this following our discussion of the new governance and green planning features of the plans and the tensions we identify between deliberative and strategic policy design.

\section{REVIEWING TASMANIA TOGETHER \& GROWING VICTORIA TOGETHER New Governance}

\section{Tasmania Together - apolitical, deliberative, power-sharing and embedded?}

It is fair to acknowledge that there has been cynicism about and criticism of Tasmania Together from the community and political parties, although it was initially established with tripartite support from the Government, and the Liberal and Green Opposition parties. The Liberals now oppose it and the Greens no longer overtly support it. Before the process was handed over to an independent secretariat, there was also a view that the Community Leaders Group was a partisan body under the control of Labor's Leader in the Legislative Council Michael Aird. The process has also always been strongly associated with the reforms of the Bacon government and the late Premier personally, although it is now endorsed by his successor. And there has always been a lack of trust by critics of the process which is seen as disingenuous coming from a government that had won office after supporting a reduction in Lower House numbers (McCall and Hay 2005).

When in opposition, immediately prior to winning power in the 1998, Labor had supported the Liberal minority government initiative to reduce Lower House numbers in an attempt to prevent another minority government. This successful move was broadly condemned as an antidemocratic attempt to wipe out the Greens and undermine the deliberative potential of the Hare Clarke electoral system. This move was seen to be a rejection by the major parties of the notion of sharing parliamentary power. Although Tasmania Together is a deliberative project, it is not designed to share power, nor to carry the voices of dissenters such as the Greens, but it is designed to see broad community agreement on ways forward translated into policy. It is well embedded by legislative and governance processes, and its board and secretariat, and it drives agency policy agendas, agency budgets, and progress towards community goals.

\section{Growing Victoria Together - apolitical, deliberative, power-sharing and embedded?} The public origins of Growing Victoria Together rest with the Growing Victoria Together Summit held in March 2000 (Office of the Premier and Treasurer 2000). One hundred public figures including Ministers, the Leader of the Opposition, an independent Member of Parliament, and union, community and business leaders discussed future directions for the state ${ }^{9}$. This culminated in the development of recommendations to Government, the establishment of the Victorian Economic, Environmental and Social Advisory Council (VEESAC) (a nonstatutory advisory body comprising community leaders), and the release of a unanimously agreed Communiqué. Despite these origins, by November 2001 when the Premier released

\footnotetext{
${ }^{8}$ Interestingly neither process was inclusive of the green activist or environmental policy communities.

${ }^{9}$ There were only two participants representing environmental interests.
} 
Growing Victoria Together it was clearly a partisan document, and one that had required a sustained effort to win the support of both Ministers and Departments.

No formal public consultative mechanisms were established to provide input to the development of Growing Victoria Together with the Government relying instead on existing processes, and views provided through Community Cabinet processes and the VEESAC ${ }^{10}$. Growing Victoria Together is thus not a deliberative process, although the Government had sought support from key stakeholders for its overall priorities for Victoria for the coming decade. This may be an example of networked governance in a restricted sense, but it was not power sharing or participatory governance. Neither is Growing Victoria Together legislatively embedded into Victorian government policy process, despite efforts to track its progress, so that its survival within and beyond the life of the Labor government remains discretionary.

\section{Green Planning}

\section{Tasmania Together - Comprehensive, Participatory, Integrated, Adaptive?}

Whereas Tasmania Together has strengths in terms of its commitment to deliberative policy design, it has weaknesses in terms of its capacity to offer a comprehensive approach to environmental policy design and sustainability planning. The content of Tasmania Together is derived from public opinion, which is on the whole partial, self interested and populist rather than comprehensive. Neither is there the capacity for minority, dissenting views to be captured in a process designed to collect and categorise majority opinion and concerns. Neither is it legitimate to rewrite public opinion and concern to reflect comprehensive scientific assessments such as the state of the environment reporting process. Integration between Tasmania Together and environment processes that are well informed is a sporadic affair, with links generated when looking for discrete data sources by which to create standards and goals for deliberatively derived benchmarks to be tracked over time.

The result is that Tasmania Together can only ever present a partial, piecemeal approach to the environment that is the result of admitting into its goals only those issues of public concern that are captured by its participatory processes. In terms of sustainability planning, it is thus only a partial tool to sit alongside other tools. The problem with relying upon deliberative design is that it is not substantive in its appreciation of ecological problems, nor purposeful in shifting commitment into action, nor comprehensive in its scope and application. Tasmania Together is only intended to track rather than solve problems over time, and only tracks those agreed by public consensus, and the very obvious rather than the very legitimate problems. On the other hand, once a problem is identified and written into the plan, the full machinery of government can swing behind it. In this sense populist concerns can be addressed in an integrated cross-agency, cross-sectoral fashion, with the exception of the more politicised demands such as an end to old growth logging and 1080 poisoning for instance (Crowley 2006).

\section{Growing Victoria Together - Comprehensive, Participatory, Integrated, Adaptive?}

As a whole of government policy framework which encompasses environmental, social and economic objectives Growing Victoria Together is a broad statement of the Government's vision for the next 10-20 years. There is coverage of policy arenas such as health, education, jobs, environment etc., although the priorities adopted for each of these does not appear to be informed by systematic analysis, or public deliberation or consultation. Indeed the credentials of Growing Victoria Together as a deliberative approach to green planning are limited by the lack of public consultation associated with its development, implementation and review, with consultation only amongst elites. The focus is partly influenced by symbolism, such as the restoration of flows to the Snowy River rather than a commitment to restoring river health.

There is also a lack of connection between Growing Victoria Together and state policy, which could be forged to provide detailed coverage of what the is doing, and there is also a lack

\footnotetext{
${ }^{10}$ See Adams and Wiseman (2003) for a more detailed explanation of the consultation mechanisms used
} 
of robust mechanisms for tracking and evaluating progress. These deficits severely limit the capacity of Growing Victoria Together to provide a comprehensive and adaptive approach to green planning, which is disappointing given its breadth of scope. Growing Victoria Together also adopts a 'balanced' rather than 'integrated' approach to sustainability so that environmental, economic and social objectives are traded off, and environmental issues are treated as discrete responsibilities rather than as integrated concerns across government (which in effect, means that environmental concerns may not be fully considered in determining economic directions and priorities).

The new governance and green planning features of Tasmania Together and Growing Victoria Together are summarised below showing the differences, on deliberation for example, and similarities, on power sharing for example, between the plans. Whilst the impetus of both was community disillusionment and dissatisfaction with state politics, it is Tasmania that has most embraced the new governance challenge of collaborative state planning. However it is Victoria that has more clearly embraced the strategic challenge of adopting a well developed, widely distributed policy framework, with economic, social and environmental objectives. The sub-national planning dilemma could then be seen as one between pursuing deliberation as a means of securing public legitimacy, and pursuing strategic design as a means of securing more political state policy priorities. There is nothing to suggest that either approach is more suited to achieving sustainability, indeed both deliberative and strategic principles are critically important, provided they do not operate at cross purposes.

\begin{tabular}{|l|l|l|l|l|}
\hline New Governance & apolitical? ${ }^{\mathbf{1 1}}$ & deliberative? & power sharing? & embedded? \\
\hline $\begin{array}{l}\text { Tasmania } \\
\text { Together }\end{array}$ & intended to be & $\begin{array}{l}\text { bottom up } \\
\text { deliberative }\end{array}$ & $\begin{array}{l}\text { no, potentially but } \\
\text { not actually }\end{array}$ & $\begin{array}{l}\text { very effectively } \\
\text { and beyond } \\
\text { government }\end{array}$ \\
\hline $\begin{array}{l}\text { Growing } \\
\text { Victoria Together }\end{array}$ & not intended to be & $\begin{array}{l}\text { no, top down } \\
\text { strategic through } \\
\text { established paths }\end{array}$ & $\begin{array}{l}\text { no, guiding only, no } \\
\text { public dialogue }\end{array}$ & $\begin{array}{l}\text { no formal, } \\
\text { inclusive } \\
\text { mechanisms }\end{array}$ \\
\hline Green Planning & comprehensive? & purposeful? & integrated? & adaptive? \\
\hline $\begin{array}{l}\text { Tasmania } \\
\text { Together }\end{array}$ & $\begin{array}{l}\text { no, based on } \\
\text { attentive public } \\
\text { input only }\end{array}$ & $\begin{array}{l}\text { measures progress } \\
\text { towards } \\
\text { benchmarks }\end{array}$ & $\begin{array}{l}\text { environmental } \\
\text { policy integration } \\
\text { potential }\end{array}$ & $\begin{array}{l}\text { very effectively } \\
\text { with mandated } \\
\text { reviews }\end{array}$ \\
\hline $\begin{array}{l}\text { Growing } \\
\text { Victoria Together }\end{array}$ & $\begin{array}{l}\text { broad, not } \\
\text { comprehensive } \\
\text { directions only } \\
\text { envilances } \\
\text { other goals }\end{array}$ & $\begin{array}{l}\text { only through } \\
\text { informal means } \\
\text { and as policy } \\
\text { direction }\end{array}$ \\
\hline
\end{tabular}

Table 3.

New Governance \& Green Planning Features of Tasmania Together \& Growing Victoria Together

\section{Sustainability Tensions}

With emphasis upon visions, goals and progress that is economically, socially and environmentally sound, state planning in Tasmania and Victoria has similar potential to pursue sustainability. From the perspective of new governance and green planning, however, considerable differences emerge between the states, although not necessarily to the detriment of their sustainability potential. It is important to appreciate differences of scale between the states as well, with the Tasmanian plan designed for a relatively small, highly decentralised, island community, and the Victorian plan designed for a much greater population and region. Perhaps by consequence, the Tasmanian plan is itself a policy driver, identifying and tracking specific community objectives, whereas the Victorian plan is a macro-contextual device that broadly stimulates policy in a non-prescriptive way. There is scope therefore for Tasmania to adopt

\footnotetext{
${ }^{11}$ Growing Victoria Together operates with a high degree of politicisation of its aims and aspirations at election time, in contrast to the total absence of Tasmania Together from electoral politics.
} 
more purposeful benchmarks linked to its state of environment reporting, and for Victoria to enhance the sustainability emphasis of its macro-policy setting. We turn now to the tensions we encountered in our new governance and green planning for sustainability analysis.

\section{Deliberative-Strategic Tensions}

The first difference is of style, between deliberative (ie Tasmania Together) and strategic (ie Growing Victoria Together) processes. Our review has identified theoretical tensions between the notions of deliberation on the one hand and strategic planning on the other as differing ways of constructing state policy and planning. These tensions are reflected in the case studies with Tasmania's emphasis upon the community as policy innovator, and Victoria's upon the state as policy director. There are similar tensions between the deliberative and strategic approaches to sustainability, in terms of entrusting its pursuit to the community or to a strong state, with public deliberation recognised as often a real threat to strategic environmental planning (Meadowcroft 2004:186-7). This tension can be seen more positively as policy dynamism or interaction (after Akkerman, Hajer and Grin 2004), in the sense that Tasmania Together is deliberatively derived, but politically controlled, driven, resourced, managed and implemented.

\section{Empowering-Promoting Change Tensions}

There is also tension between sustainability planning as empowering, or as a way of promoting change for the improved conservation and enhancement of ecological processes over the long term. In Tasmania we see the emphasis upon empowerment and the long term, and in Victoria upon the traditional political priorities and electoral cycles. There are drawbacks to both Tasmania's deliberative design for not producing a plan that is informed by a critical understanding of ecological problems, and to Victoria's elitist design for its failure to consult the public. However whilst there is scope for expert input in the benchmarking phase of Tasmania Together to complement deliberative design, there are no deliberative processes built into Growing Victoria Together to counter its policy elitism. Again we would advocate policy dynamism with activities for community empowerment situated within the macro-context of a politically driven sustainability strategy as most consistent with new governance approaches.

\section{Institutional-Political Tensions}

For sustainability efforts to be lasting and effective they need to be institutionalised. There is nothing to suggest that there is any best way of doing this, in Tasmania Together planning and benchmarking, for instance, or in the implementation of the Growing Victoria Together plan. Most notable in our review was the effective implementation of Tasmania Together which is well managed and well supported politically, with an enviable dynamism achieved between political intent, community will and bureaucratic efforts. Whilst Growing Victoria Together is a more rhetorical project, it does promote sustainable development explicitly and aims to protect the environment for future generations (which Tasmania Together does not), but it does not commit to resources, processes, legislation, robust benchmarks nor independent monitoring. The difference between the two plans in terms of potentially pursuing sustainability is that whilst Tasmania is a more deliberative process with effective implementation, Victoria's approach is more closely associated with policy leadership from within government.

Casting these tensions as dynamisms is a conceptual shift that avoids finding that Tasmania is better placed than Victoria for pursuing sustainability or vice versa, and indeed reinforces the message that there is no one best governance approach to sustainability (Lafferty 2004). Indeed, as we have argued, there are elements of the plans that are complementary as much as contrasting. So we can argue that state sustainability efforts will not easily succeed where they exclude the public on one hand, or where they are not set in a strategic context and given political imprimatur on the other. It is less clear that sustainability governance must 
absolutely be an empowering process, although empowerment that includes knowledge generation and dissemination will enhance the community's sustainability efforts. Probably most significant is the institutionalisation of a well resourced policy process for sustainability planning, combined with policy leadership from state premiers and the bureaucratic elite, and which engages in dialogue with the community.

\section{CONCLUSIONS}

Tasmania Together and Growing Victoria Together are very different sub-national attempts at well developed and widely distributed policy frameworks, that set out economic, social and environmental objectives and mark a resurgence in state planning. Tasmania Together is a bottom-up deliberative framework that is nevertheless strategically rational and in pursuit of clear objectives, whilst Growing Victoria Together is a rhetorical plan against which to broadly measure policy progress. Whilst Tasmania Together is a reflection of community priorities, Growing Victoria Together is a reflection of political priorities including the need, however, to readmit social and environmental factors back into the decision-making equation. The plans are respectively committed to environmental goals and the triple bottom line. However, where they balance rather than integrate the environment with other concerns, they encourage a trade off mentality that is a limitation in terms of pursuing suitability ${ }^{12}$.

What each framework offers, if not the promise of delivering sustainability, is the potential for green planning to achieve it, with Tasmania Together in the better position of having well embedded, legislative mandates for setting goals, benchmarks, monitoring and for independent evaluation and reporting. This process already sets milestones such as Buhrs (2000) recommends for demonstrable improvements in environmental quality, in generating or strengthening public support for environmental measures and in enhancing transparency and accountability. The State of Environment reporting process in both states could adopt this degree of rigor in benchmarking. Victoria has set broad goals compatible with the pursuit of sustainability, but is lacking the implementation detail, extended time horizon, public participation, transparency and accountability to deliver quality environmental planning. The Office of the Commissioner for Environmental Sustainability could provide an independent assessment of Growing Victoria Together's impact upon progress towards sustainability ${ }^{13}$. Tasmania could establish a similar office, and better integrate its environmental policy efforts.

Whilst both frameworks have been devised in response to the need to reorient public policy to readmit the concerns of the community, Tasmania Together is the better example of new governance in terms of actually shifting policy making power over to the community. The sharing of power and bone fide public involvement in policy development is discussed above as a critical means of overcoming public cynicism and distrust of political agendas. It remains to be seen over the long term how far Tasmania Together contributes to the real sharing of power in the state and what conflicts arise between political and community agendas. In the short term, despite its endorsement of Tasmania Together and the link between community benchmarks and state budgets, policies and priorities, the State government has set itself apart from the independent Tasmania Together Progress Board. The state may be the creator, legal regulator and financial provider of the process, but it sees itself as a participant in the process and in the pursuit of long-term community goals. By contrast it is clearly the state that is driving and controlling Growing Victoria Together.

In terms of theory, both frameworks point to an interesting contradiction between the rational, purposeful and strategic elements of planning and the contingent, deliberative elements

\footnotetext{
${ }^{12}$ As a result some of the policy directions and goals may work against others, for example within Growing Victoria Together the Government's commitment to the construction of the Scoresby Freeway may undermine environmental sustainability objectives. Similarly the Tasmania Together goals of increasing mineral exports, population and economic growth each have the capacity to undermine environmental sustainability objectives

${ }^{13}$ Although the powers granted to the Commissioner under the relevant legislation are restrictive.
} 
of new governance. Tasmania Together illustrates a dynamic, interactive combining of these contrasting elements, with its politically driven, yet strategic, priority-setting approach that is community owned in terms of future visions. Growing Victoria Together is a more traditional, top down, strategic planning, policy reorientation exercise, not community owned or driven and very much an overtly political tool. There is clearly a case for politicised planning, and indeed it has great strengths for stamping new directions on the activity of government, and for controlling those new directions in the face of potential derailing interests. From our review of the new governance and green planning features of both state plans, we have highlighted several key tensions, in terms of state capacity to pursue sustainability, which could be managed in a positive sense as policy dynamisms or interactions. State sustainability governance would therefore be deliberative within a strategic context, empowering of the community but guided in a purposeful sense by the state, adequately resourced, with effective processes, legislation, and with monitored targets.

\section{REFERENCES}

Adams, D. and J. Wiseman. 2003. 'Navigating the future: a case study of Growing Victoria Together.' Australian Journal of Public Administration 62(2):11-23.

Akkerman, T., M. Hayer and J. Grin. 2004. 'The Interactive State: Democratisation from Above.' Political Studies Vol 52: 82-95.

Bingham, L. B., T. Nabatchi and R. O'Leary. 2005. 'The New Governance: Practices and Processes for Stakeholder and Citizen Participation in the Work of Government.' Public Administration Review 65(5):547-558.

Bishop, P., and G. Davis. 2001. 'Developing Consent: Consultation, Participation and Governance' in Are You Being Served?: State, Citizens and Governance, eds. G Davis and P. Weller. Sydney: Allen and Unwin.

Bridgman, P., and G. Davis, G. 2000. The Australian Policy Handbook. $2^{\text {nd }}$ edition, Sydney: Allen and Unwin.

Buhrs, T. 2000. 'Green planning in Australia and Canada: Dead or Alive?' Environmental Politics 9(2):102-125.

Chappell, T (2001) Vic - Bracks Denies He's on a Road to Nowhere, AAP News [AAP Information Service accessed via Dow Jones Interactive sites, date accessed 21/06.02]

CLG [Community Leaders Group]. 2000. A Vision for Tasmania in 2020. GPO Box 123 Hobart 7000: Tasmania Together Community Leaders Group.

Coffey, B. and A. Major. 2005. 'Towards More Integrated Natural Resource Management in Victoria: Possible Elements of an Integrated State-Wide Policy Framework.' Australasian Journal of Environmental Management 12(3) Supplementary Issue:29-38.

Commonwealth [Commonwealth of Australia].1992. National Strategy for Ecologically Sustainable Development. Canberra: Australian Government Publishing Service.

Considine, M. 2005. Making Public Policy: Institutions, Actors, Strategies. Cambridge: Polity Press.

Crowley, K. 2006. 'Tasmania Together: Participatory Policy Making for Sustainability.' in Beyond the Policy Cycle: the Policy Process in Australia, ed. H. K. Colebatch. Sydney: Allen and Unwin.

Dalal-Clayton, B. 1996. Getting to Grips with Green Plans: National Level Experience in Industrialised Countries. London: Earthscan Publications.

Davis, G. and P. Weller, eds. 2001. Are You Being Served?: State, Citizens and Governance. Sydney: Allen and Unwin.

Dovers, S. 1999. 'Institutionalising Ecologically Sustainable Development: Promises, Problems and Prospects.' in Australian Environmental Policy: Studies in Decline and Devolution, eds. K. Walker and K. Crowley. Kensington, NSW: UNSWPress. 
DPC [Department of Premier and Cabinet]. 2000. Twelve Months on ... and Beyond: The Bracks Government's Key Achievements Since the $20^{\text {th }}$ of October 1999 and a View of the Year Ahead, Melbourne: Government of Victoria.

DPC [Department of Premier and Cabinet]. 2001. Growing Victoria Together: Innovative State, Caring Communities, Melbourne: Government of Victoria.

Ferguson, J (2001) 'Bracks Sets New Goals' Herald Sun 24.11.01, p20.

Hannan, E (2001) 'Bracks to Declare Blueprint for State' The Age, 23.11.01, p8.

Hayward, D. and P. Ewer. 2003. Visions for Victoria, The Vulgar Press: Carlton North, Victoria.

Hertin, J. and F. Berkhout. 2003. 'Analysing Institutional Strategies for Environmental Policy Integration: the Case of EU Enterprise Policy.' Journal of Environmental Policy and Planning 5(1):39-56.

Hodgett, S. and D. Johnson, D. 2001. 'Troubles, Partnerships and Possibilities: a Study of the Making Belfast Work Development Initiative in Northern Ireland.' Public Administration and Development 21:321-332.

Kay, R. and J. Adler. 1999. Coastal Planning and Management London: Routledge.

Kent, K (2000) 'Tasmania Together' Communique: the Newsletter of the Institute of Public Administration Australia [Tasmania Division inc.] July:1-3.

Lafferty, W. M. ed. (2004) Governance for Sustainable Development: the Challenge of Adapting Form to Function. Cheltenham UK, Northhampton, MA, USA

Lundqvist, L. J. 2001 'Implementation from Above: The Ecology of Power in Sweden's Environmental Governance.' Governance: An International Journal of Policy and Administration 14(3):319-337.

McCall, T. and P. Hay. 2005. 'Jim Bacon/Paul Lennon: The Changing of the Guard - from 'the Emperor' to 'Big Red.' in Yes, Premier: Labor Leardership in Australia's States and Territories, eds. J. Wanna and P. Williams, Sydney: University of New South Wales Press.

Mackie, T. and D. Marsh. 1995. 'The Comparative Method.' in Theories and Methods in Political Science, eds. D. Marsh and G. Stoker. London: Macmillian Press.

Meadowcroft, J. 2004. 'Participation and Sustainable Development: Modes of Citizen, Community and Organisational Involvement.' in Governance for Sustainable Development: the Challenge of Adapting Form to Function, ed. W. M. Lafferty. Cheltenham UK, Northhampton, MA, USA.

O’Neill, D. 2000. 'Victoria: Rolling Back - or Reinventing - the Kennett Revolution?' Australian Journal of Public Administration 59(4):109-115.

OECD [Organisation for Economic Cooperation and Development]. 2002. Improving Policy Coherence and Integration for Sustainable Development: A Checklist, Policy Brief, OECD Headquarters, Paris (www.oecd.org/dataoecd/60/1/1947305.pdf date accessed 14/9/06).

Office of the Premier. 2001. 'Premier Unveils 10 year Growing Victoria Together Plan', Media Release from Government of Victoria (www.dpc.vic.gov.au, accessed 21/12/01).

Office of the Premier and Treasurer. 2000. 'Growing Victoria Together Summit' Media Release from the Government of Victoria (www.dpc.vic.gov.au, accessed 4.07.02).

Osborne, D. and T. Gaebler. 1992. Reinventing Government: How the Entrepreneurial Spirit is Transforming the Public Sector. New York: Plume Books.

Pierre, J. and B.G. Peters. 2000. Governance, Politics and the State. Houndsmills, UK: Political Analysis Series, Macmillan.

Reddel, T. 2002. 'Beyond Participation, Hierarchies, Management and New Markets: New Governance and Place Policies.' Australian Journal of Public Administration 61(1):50-63.

Rhodes, R. 1997. Understanding Governance: Policy Networks, Governance, Reflexivity and Accountability. Buckingham: Open University Press.

Richardson, J. and A. Jordan, 1979. Governing Under Pressure: the Policy Process in a PostParliamentary Democracy. Oxford: Basil Blackwell.

Rose, R. 1991. 'Comparing Forms of Comparative Analysis.' Political Studies 39:446-62. 
Salaman, L. ed. 2002. The Tools of Government: A Guide to New Governance. New York: Oxford University Press.

Selman, P. 1999. 'Three Decades of Green Planning: What have We Really Learnt?' In Planning Sustainability, eds. M. Kenny and J. Meadowcroft. London: Routledge.

The Age (2001), 'It's time for a Bracks vision' Editorial in The Age, Tuesday 20 November 2001.

Woodward, D. and B. Costar. 2000. 'The Victorian Election of 18 September 1999: Another Case of Electoral Volatility?' Australian Journal of Political Science 35(1):125-133.

Yencken, D. 2002. 'Governance for Sustainability.' Australian Journal of Public Administration 61(2):78-89. 